\title{
Illisaġvik Tribal College's summer climate program: teaching STEM concepts to North Slope Alaska high school and middle-school students
}

\author{
Linda Nicholas-Figueroa $^{1}$ - Rebekah Hare ${ }^{2}$ - Mary van Muelken ${ }^{3} \cdot$ Lawrence Duffy $^{4}$. \\ Catherine Middlecamp ${ }^{5}$
}

Published online: 2 November 2016

(C) The Author(s) 2017. This article is published with open access at Springerlink.com

\begin{abstract}
The incorporation of informal science modules with traditional ecological knowledge (TEK) engages students in Science, Technology, Engineering, and Mathematics (STEM) courses. During the summers 2012-2015, Ilisagivik Tribal College, located in Barrow, AK, hosted an average of 12 rural Alaska Native middle-school and high school students per year in the college's summer STEM program called "Climate and Permafrost Changes on the North Slope: In Cultural Context." Teaching the carbon cycle as a core concept, this 2-week STEM program examined climate change and its effects on the local landscape from a multitude of perspectives. Elders shared their observations and experiences associated with climate change. Local and visiting scientists gave presentations and taught through games, hands-on laboratory simulations, and practical field work - all relevant to the camp's science content. Preassessments and post-assessments using the Student Assessment of Learning Gains measured student interests and conceptual understanding. Students developed and enhanced
\end{abstract}

The original version of this article was revised due to a retrospective Open Access order.

Linda Nicholas-Figueroa

linda.nicholas-figueroa@ilisagvik.edu

Ilisaġvik Tribal College, PO Box 749, Barrow, AK 99723, USA

2 University of Alaska Fairbanks, BLaST, PO Box 757580, Fairbanks, AK 99775, USA

3 Resilience and Adaptation Program, University of Alaska Fairbanks, PO Box 757580, Fairbanks, AK 99775, USA

4 Department of Chemistry and Biochemistry, University of Alaska Fairbanks, PO Box 6160, Fairbanks, AK 99775, USA

5 Nelson Institute for Environmental Studies, University of Wisconsin-Madison, 550 North Park Street, Madison, WI 53706, USA their understanding of science concepts and, at the end of the camp, could articulate the impact of climactic changes on their local environment.

Keywords STEM · Informal science $\cdot$ Climate change . Traditional ecological knowledge

\section{Introduction}

Located $300 \mathrm{mi}$ north of the Arctic Circle, the North Slope Borough is home to approximately 10,000 people residing in eight villages (Fig. 1). The majority of the residents are Iñupiat Eskimo $(>75 \%)$ whose rich cultural heritage exceeds 10,000 years (Shepro 2010). According to the official website of the North Slope Borough (NSB 2016), "Today, Iñupiat still look to the land for cultural and economic sustenance." While the Iñupiat have embraced economic and technological changes, they additionally depend on whaling, hunting, and fishing for cultural identity and much of their food supply. These practical skills and values or traditional ecological knowledge (TEK) are passed from Elders to youth, providing a dynamic cultural connection that uses observational methods and storytelling to examine environmental change. Global warming, a growing community concern, for example, may have significant impacts on the local environment and waters. Changes in ice are already occurring with the high rate of sea-ice decline leading to unstable ice conditions, which could create tremendous dangers during the winter hunting season for seals, walrus, and whales. Erosion, thawing permafrost, and changes in plant and animal migration are also affected by a warming climate.

Over the last 60 years, Alaska has experienced a $6^{\circ} \mathrm{F}$ increase in winter temperatures and a $3{ }^{\circ} \mathrm{F}$ increase overall, twice that of the rest of the planet (EPA 2015). On the North 


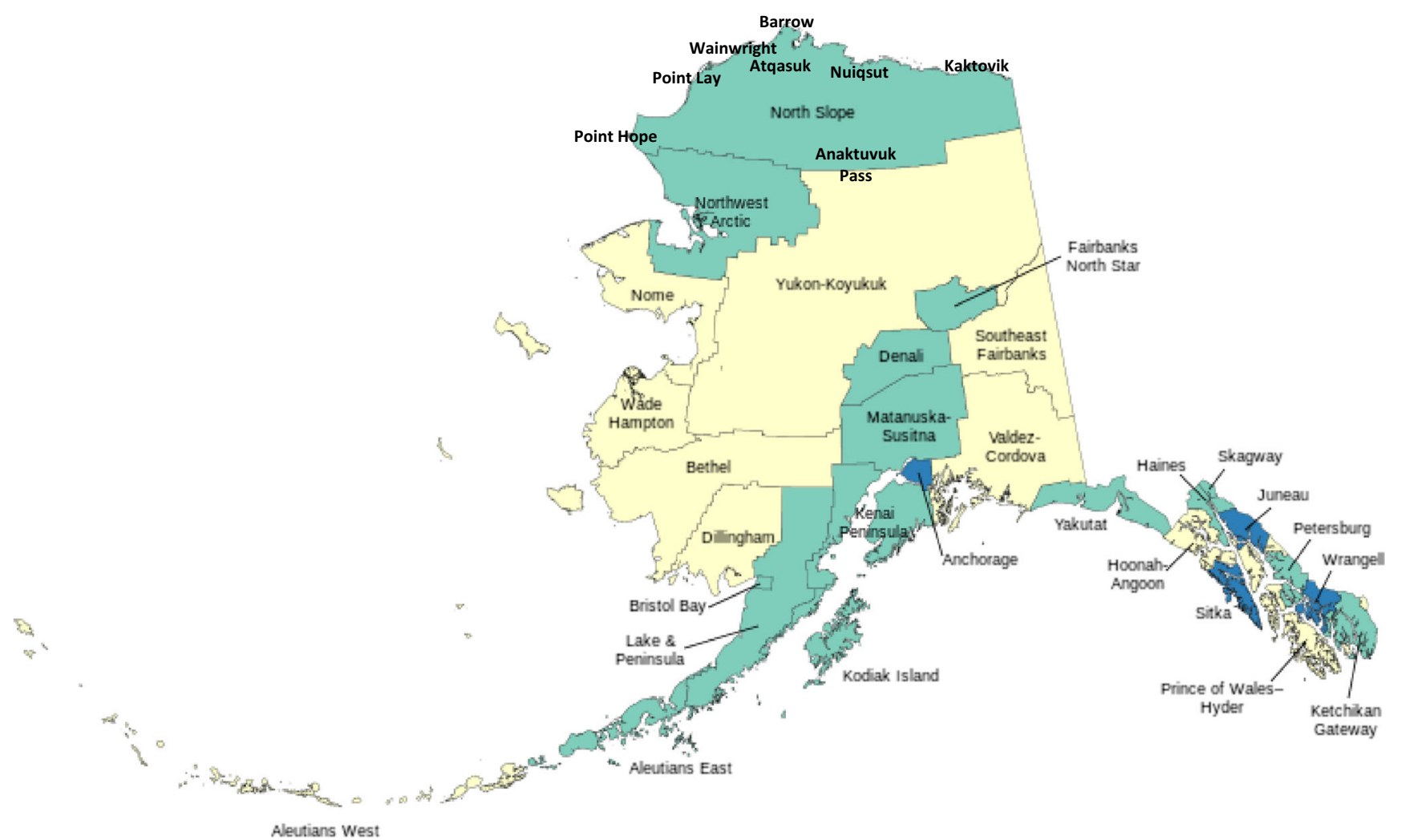

Fig. 1 Map of the North Slope Borough (NSB) used with permission from the NSB Department of Planning/GIS Division (source, http://www. north-slope.org/assets/images/uploads/NSBCensus2010.pdf.). Barrow, $\mathrm{AK}$, is the most populated village averaging around 4500 people, $61 \%$

Slope, the resultant ecological changes have been both positive and negative. Personal witnesses to global warming, North Slope youth are observing significant changes to the landscape. Although local and national leaders are addressing climactic concerns and adaptation and resilience protocols are being formed, it is imperative that North Slope youth are informed as well. Knowledge of current climate science theory and practice can give students the confidence needed to become active members and voices within their communities when strategic choices to mitigate climate change impacts are required (Perkins et al. 2014). Alaska Native youth often are confronted with straddling the fence in a world of technological advances and traditional knowledge. This program is designed to enhance student learning by blending lessons of Western science and discussions with Elders on TEK on environmental issues associated with climate change. Selfassessment is utilized to help determine if students have an increase of knowledge at the end of the program.

Up to the early 1900s, Native knowledge and Western science were classified as two mutually independent systems (Barnhardt 2005; Stephens 2000). By the nineteenth century, an extensive amount of literature compared these two systems. While Western science is transmitted through academics and literature, on the contrary, traditional knowledge is transmitted being Alaska Native. The remaining village (Anaktuvuk Pass, Atqasuk, Kaktovik, Nuiqsut, Point Hope, Point Lay, and Wainwright) populations range from 900 to 200 people, $90-95 \%$ being Alaska Native

through generations of oral story telling by Elders (Fulvio Mazzocchi 2006; Medin and Bang 2014). Isolation of the objects of study, or separation from nature, is common in Western science, while traditional knowledge consistently depends on its environment and its distinct conditions (Nakashima and Roué 2002). As pointed out by Greg Lowan (2012), tensions between Western and Indigenous science have led to scholars such as Gregory Cajete, Ray Barnhardt, and Angayuqaq Oscar Kawagley to seek a common ground, "an existential and epistemological meeting place" between traditional Native knowledge and Western science (Fig. 2). Today, relationships between local and visiting educators, scientists, community scholars, and Elders can facilitate closing the TEK and Western science gap.

Climate and Permafrost Changes on the North Slope: In Cultural Context program was developed through a partnership with Ilisagivik Tribal College, the University of Alaska Fairbanks, and supporting collaborators. This program is a short two-credit course but runs in an interactive manner. Student selection was primarily based on students' interest in science, but anyone was eligible to apply. For example, one student's main interest was in culinary arts, but she indicated that she was very concerned about the environmental changes occurring in her village due to climate changes. Her village, Shishmaref, is facing 
Fig. 2 From the Handbook for culturally responsive science curriculum (Stephens 2000)

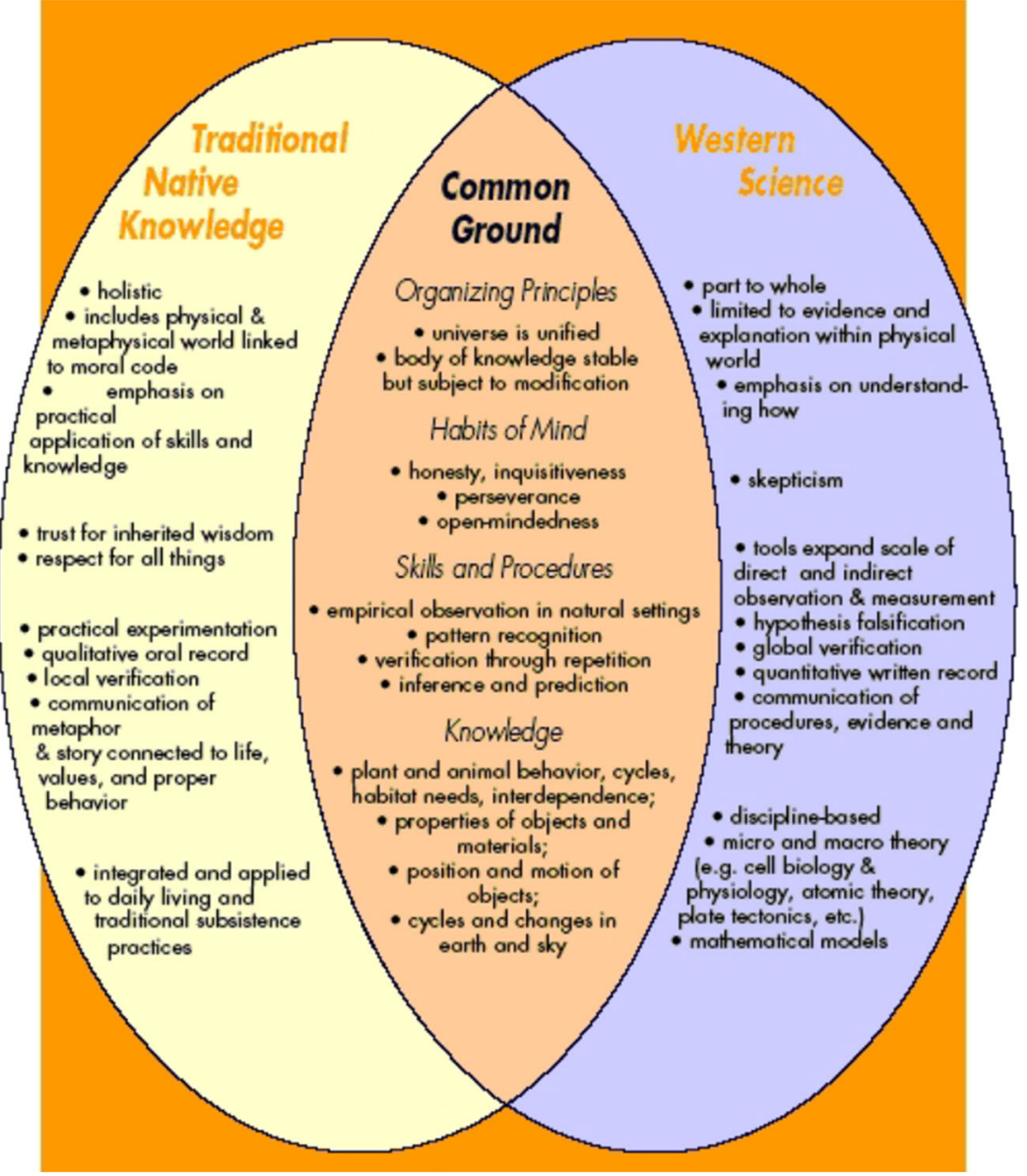

grave coastal erosion that could lead to the necessity to evacuate the entire community. As we were only looking for an increase in knowledge, GPA was not a factor in the selection of students. With Barrow being the largest community with the most student applicants, we did assure that our selection of students was from several different rural villages to include one or two outside of the North Slope Borough.

The course curriculum consists of modules that address Arctic ecology, the carbon cycle, natural resources, global warming, and the physical impacts of a warming climate (Fig. 3). Modules are a practical means of presenting scientific content to varying age groups equivalent to grades 7-12 (Nicholas-Figueroa, et al. 2015). Informal science, with a strong layer of TEK, encourages student engagement; the modules reflect the students' rural upbringing and their interaction and expertise with technology (Duffy, et al. 2011a; NicholasFigueroa, et al. 2015). Lessons, such as the physical impacts of a warming climate, included a scientific presentation, lab activities and/or field trips, and discussions with Elders leading to dynamic interactions between the students, scientists, and Elders.

\section{Methods}

\section{Student assignments}

Students attending the camp were given out-of-class assignments, maintained a daily journal, wrote a minimum 500word essay, and delivered a presentation at the end of the camp. Assignments were based on the materials that covered

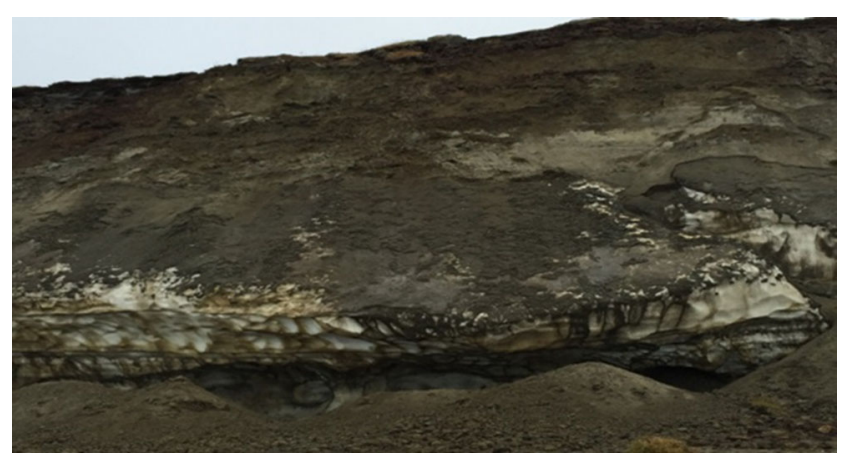

Fig. 3 Coastal erosion, Barrow, AK. Photograph by Linda NicholasFigueroa 
the periodic table, elements, carbon, combustion, greenhouse gases, and climate change. The students were required to take daily notes in their journals on the scientific lectures, handson/lab activities, Elder discussions, and field trips. The journals were collected and returned with informational comments that supplemented their notes, enhancing the learning process. Students were encouraged to write their essays on topics of interest to them. The students prepared a public presentation integrating the knowledge gained from the assignments, scientists, Elders, and fieldtrips.

\section{Meetings with scientists}

Local and visiting scientists presented information to the students through presentations, hands-on activities, laboratory simulations, and games. Foundational topics such as carbon chemistry, weather and climate, greenhouse gases, atmospheric $\mathrm{CO}_{2}$, and global warming were presented by instructional faculty: Linda Nicholas-Figueroa, Ilisaġvik College; Drs. Rebekah Hare and Lawrence Duffy, University of Alaska Fairbanks; Dr. Cathy Middlecamp, University of WisconsinMadison; and Dr. Bob Rabin, NOAA/National Severe Storms Laboratory. Visiting presenters provided a breadth of topics emphasizing the impacts and issues associated with a changing Arctic (Table 1).

\section{Meetings with Iñupiat Elders}

Exposure to traditional knowledge occurred through lessons with local Elders. Information gained from this experience will help the students to develop and enhance their personal understanding of the significant relationship and impact of climate change on their local villages/communities. These were two-way discussions between the Elders and students. There was no set format for the discussions allowing the Elders to speak freely and adapt the conversations to student inquiries (Table 2).

\section{Field trips}

An integral camp component, field trips demonstrated practical applications of conceptual topics covered by both the scientists and Elders. Students were exposed to real-time activities that correlated with lessons learned and proved concrete examples of Science, Technology, Engineering, and Mathematics (STEM) concepts learned in class. These outings additionally demonstrated the scientific importance of the North Slope Borough to scientific inquiry. Table 3 lists the sites visited, the role played in the Arctic and/or local community, and any activities that the students observed/performed during their visit.

\section{Assessment}

The Student Assessment and Learning Gains (SALG) (Seymour et al. 2000; SALG 2013), a student survey instrument developed by the Science Education for New Civic Engagements and Responsibilities (SENCER) project, was used both at the beginning and end of the camp. SENCER is a national STEM curriculum reform project initiated in 2000 with funding from the National Science Foundation. Students took a SALG pretest survey at the beginning of the camp and

Table 1 Student interaction with visiting and local scientists

\begin{tabular}{|c|c|c|}
\hline Scientist & Affiliation & Presentation topic \\
\hline Dr. Christian Andersen & University of Texas at El Paso & $\begin{array}{l}\text { Local lakes: understanding of long-term changes } \\
\text { in biological, hydrological, and chemical systems } \\
\text { due to climate change. }\end{array}$ \\
\hline Dr. Robert Hollister & Grand Valley State University & Vegetation: the importance of global warming and the response of changing tundra. \\
\hline Dr. Jenny Cunningham & University of Missouri & Shoreline birds: change in migration patterns with warming climate. \\
\hline Dr. Debendra Das & University of Alaska Fairbanks & Permafrost: the effects of thawing permafrost on infrastructure. \\
\hline Dr. Craig George & $\begin{array}{l}\text { Department of Wildlife } \\
\text { Management, Barrow AK }\end{array}$ & Bowhead whales: early plankton bloom may change feeding patterns. \\
\hline Dr. Robert Sudyam & $\begin{array}{l}\text { Department of Wildlife } \\
\text { Management, Barrow AK }\end{array}$ & Beluga whales: offshore drilling can change migratory patterns. \\
\hline Dr. Justin Bagley & University of Illinois & $\begin{array}{l}\text { Land cover change/global food production and climate } \\
\text { change: how will food and energy crops meet global } \\
\text { demands, and how those demands will impact the environment. }\end{array}$ \\
\hline Dr. Eric Wilkman & University of California San Diego & Biogeochemical cycles: climate change and the role \\
\hline Dr. Katherine McEwing & University of Sheffield, UK & $\begin{array}{l}\text { of greenhouse gases in the atmosphere and the carbon } \\
\text { cycle and the roles of plants and microbes. }\end{array}$ \\
\hline Dr. Chris Cuomo & University of Georgia & Permafrost and thawing lakes as witnessed by \\
\hline Dr. Wendy Eisner & University of Cincinnati & Elders, hunters, and berry pickers. \\
\hline
\end{tabular}


Table 2 Student interaction with North Slope Borough Elders

\begin{tabular}{|c|c|c|}
\hline Elder & Affiliation & Presentation topic \\
\hline Mr. James Nageak & $\begin{array}{l}\text { Iñupiat History, Language and Culture } \\
\text { Commission and Ilisagvik College } \\
\text { Board of Trustees }\end{array}$ & $\begin{array}{l}\text { The dilemma of roads: there is a proposal to build a } \\
\text { road to Anaktuvuk Pass. This could be a positive } \\
\text { economic impact as foods and other goods would } \\
\text { not have to be flown in versus the potential impacts } \\
\text { of loss of wildlife and cultural integrity. }\end{array}$ \\
\hline Ms. Ida Olemaun & $\begin{array}{l}\text { Arctic Slope Regional Cooperation } \\
\text { Board of Directors }\end{array}$ & $\begin{array}{l}\text { Tourism and culture: with the Northwest Passage } \\
\text { opening up, tourism is on the rise. This can be } \\
\text { economically beneficial, but such things like cruise } \\
\text { ships can cause concerns for the ecological environment } \\
\text { and culture. }\end{array}$ \\
\hline Mr. Nate Olemaun & Whaling Captain & $\begin{array}{l}\text { Sea ice loss: storms are becoming more frequent } \\
\text { due to the loss of sea ice, which leads to } \\
\text { beach and land erosion. }\end{array}$ \\
\hline Ms. Martha Stackhouse & $\begin{array}{l}\text { Ilisagivik College Coordinator for } \\
\text { Teachers of the Arctic }\end{array}$ & $\begin{array}{l}\text { North Slope plants: invasive plant species } \\
\text { are moving North bringing in more berries, } \\
\text { but some new tall grasses might be harmful } \\
\text { for the native plant species }\end{array}$ \\
\hline Mr. Robert Suvlu & $\begin{array}{l}\text { Uquautchim Uglua (Early Childhood } \\
\text { Learning) Iñupiaq Culture-Based } \\
\text { Coordinator at Ilisagivik College }\end{array}$ & $\begin{array}{l}\text { Traditional knowledge: importance of learning } \\
\text { how to read and respect the environment and } \\
\text { paying close attention to the rapid environmental } \\
\text { changes are crucial for adaptation. }\end{array}$ \\
\hline Mr. Eugene Brower & $\begin{array}{l}\text { Arctic Slope Regional Corporation } \\
\text { Board of Trustees and President } \\
\text { of Barrow Whaling Captains Association }\end{array}$ & $\begin{array}{l}\text { Thinning sea ice and ice-cellars: dangerous } \\
\text { conditions during spring whaling, which occurs } \\
\text { on the edge of the ice. Most hunted meats } \\
\text { (whale, caribou, seal, and walrus) are stored } \\
\text { in ice cellars. Foods stored in ice cellars are } \\
\text { spoiling due to melting permafrost. }\end{array}$ \\
\hline
\end{tabular}

Table 3 Program field trips

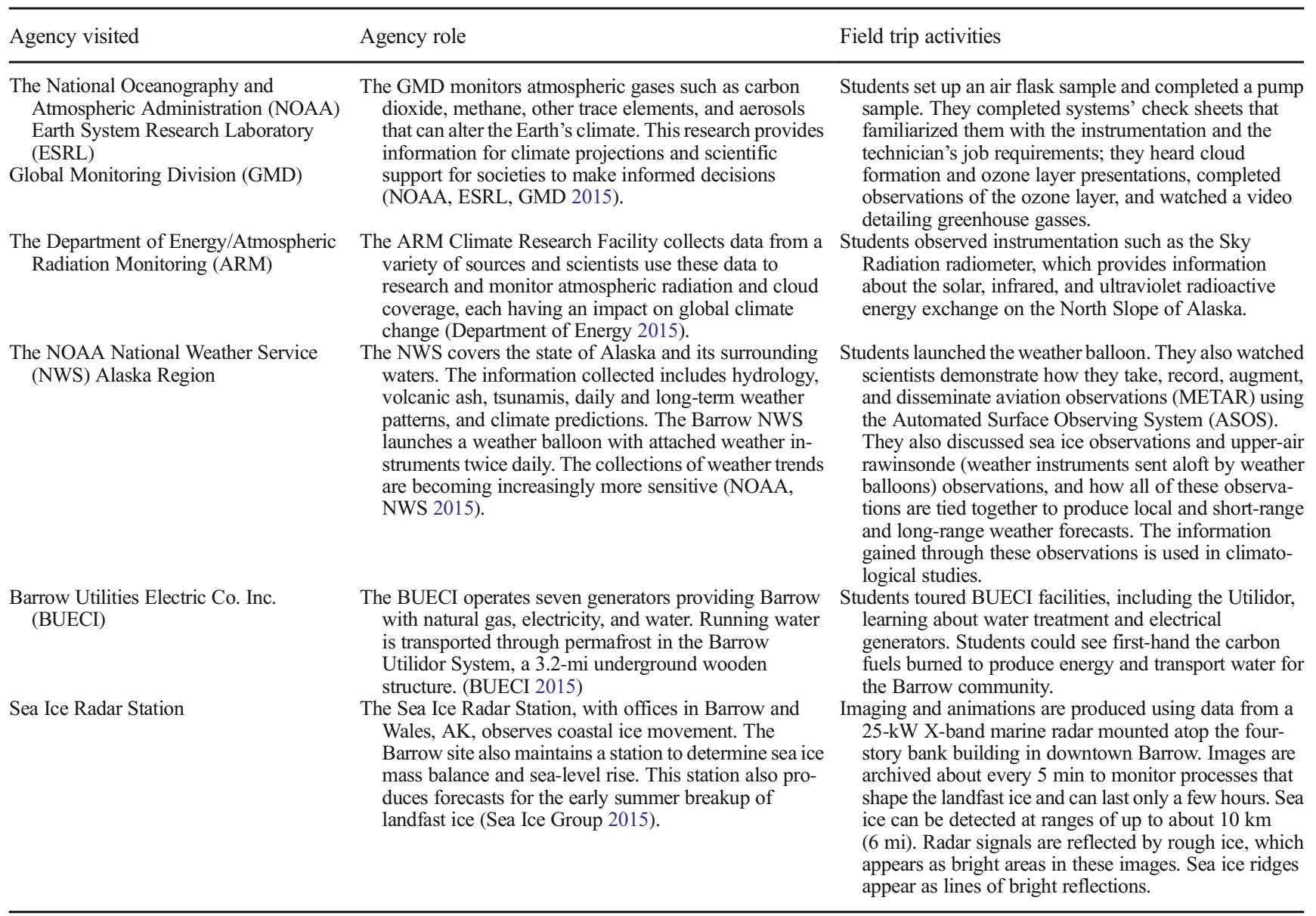


repeated it as a post-test. The analysis focused on student selfassessment of understanding of how topics relate to (1) greenhouse gases and the carbon cycle, (2) burning of fossil fuels, (3) their village, and (4) other real-world issues. The six unit Likert scale response options to a statement were 1: not applicable; 2: not at all; 3 : just a little; 4: somewhat; 5 : a lot; and 6: a great deal. Using the SENCER rubric is like performing a mental audit; each student makes a qualitative assessment of their knowledge or understanding of the issue. The instructional faculty can view the summation of the student gains as follows: not observed (scale values 1 or 2), basic (scale values 3 or 4), a lot (advanced, scale value 5, greater presence of knowledge), and a great deal (transformative, scale value 6 , sees relationships). The SALG instrument does not identify individual students and automatically calculates means and standard deviations and generates graphs of the data (Duffy et al. 2011b).

\section{Conference attendance}

Many rural Alaska Native villages are only accessible by airplane rendering travel difficult and expensive. However, it is important for rural Alaska Native students to travel and be exposed to scientific or other academic conferences. Conference attendance is a positive way to enhance and reinforce the students' learning gains as they interact with scientists and other students from many different geographical regions. Two conferences were selected for the students to attend: the 18th Inuit Studies Conference and the Society for the Advancement of Chicanos/Hispanics and Native Americans in Science National Conference. Both conferences offer students the opportunities to gain soft skills such as learning how to communicate scientific data.

\section{Results}

Using the SALG assessment tool, students reported how class activities such as lectures, discussions with Elders, and field trips helped their comprehension of the topics discussed (Table 4). Students report a general increase in learning about all topics with the exception of "what global warming is."

Students reported the significant learning gains for "the burning of methane" $(p \leq 0.01)$ and "what are biogeochemical cycles" ( $p \leq 0.002)$. Figures 4 and 5 illustrate the gain in knowledge for the understanding of "what greenhouse gases are" $(p \leq 0.01)$ and "how these topics can relate to my village" $(p \leq 0.009)$.

Using assignments, journal entries, and an essay, the students created presentations delivered to Ilisagivik College staff and community members. Each student selected an issue of personal interest and learned presentation organizational and public speaking skills. Students were evaluated in these areas; however, the majority of the grade was based on knowledge of content. Table 5 lists the titles of the student presentations.

\section{Discussion}

Understanding the carbon cycle and its impact on climate change was the recurrent theme of the 2-week program. Instructors Middlecamp, Duffy, Nicholas-Figueroa, and Hare introduced the concept of the carbon cycle and spent 2 days reinforcing the concept through a variety of activities. The message was threefold: (1) carbon is found in many places, (2) carbon moves from place to place, and (3) where it ends up matters. The fact that carbon dioxide is a colorless, odorless gas and essentially "invisible" makes the communication of this message, in a manner that maintains student attention, a significant challenge. Students cannot "see" carbon in grazing
Table 4 Mean and standard deviation values of questions answered by students prior to the beginning of camp and answers to the same questions at the end of camp

\begin{tabular}{lllll}
\hline $\begin{array}{l}\text { Topic } \\
\text { Presently I understand... }\end{array}$ & $\begin{array}{l}\text { Mean } \\
\text { pretest }\end{array}$ & $\begin{array}{l}\text { STD } \\
\text { pretest }\end{array}$ & $\begin{array}{l}\text { Mean post- } \\
\text { test }\end{array}$ & $\begin{array}{l}\text { STD post- } \\
\text { test }\end{array}$ \\
\hline How elements are organized on the periodic table & 3.9 & 0.83 & 4.1 & 1.25 \\
The burning of methane* & 3.2 & 1.67 & 4.8 & 1.04 \\
What greenhouse gases are* & 4.6 & 1.41 & 5.8 & 0.46 \\
The differences between weather and climate & 4.9 & 1.13 & 5.6 & 0.74 \\
What global warming is & 5.2 & 0.89 & 5.2 & 1.16 \\
Why air is monitored & 4.2 & 1.75 & 4.5 & 1.31 \\
The importance of permafrost & 5.1 & 0.83 & 5.5 & 0.76 \\
What biogeochemical cycles are* & 2.2 & 1.04 & 3.8 & 0.89 \\
How topics covered can relate to my village* & 4.5 & 0.93 & 5.6 & 0.74 \\
How studying the subject helps people address real- & 4.8 & 1.04 & 4.9 & 1.13 \\
$\quad$ world issues & & & & \\
\hline
\end{tabular}

*Significant at $p<.05$ 
Fig. 4 Student Assessment and Learning Gains (SALG) results for the question "I understand what greenhouse gases are." Pretest and post-test means were significantly different, $p \leq .01$

I understand what greenhouse gases are.

a

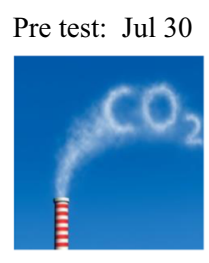

Mean 4.6

Std. 1.41

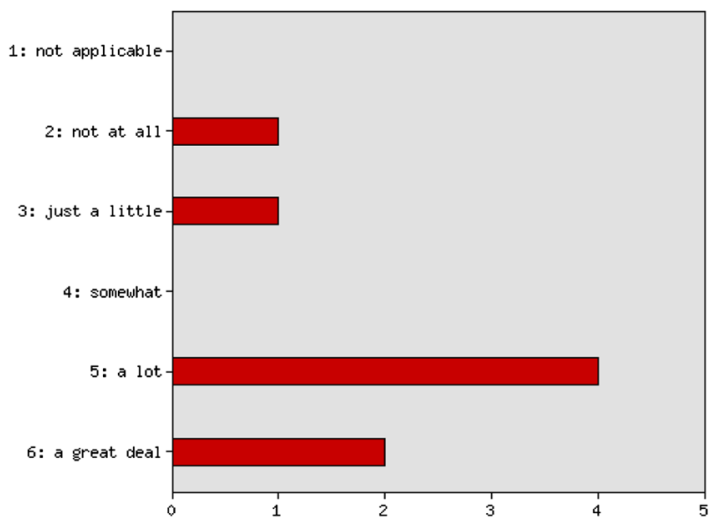

- Suminer 2013

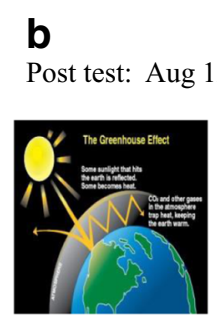

Mean 5.8 Std. 0.46 caribou, their breakfast cereal, or a graphite pencil, all seemingly unrelated objects. Compounding the issue further is the fact that carbon is found in many chemical forms ranging from methane to crude oil to whale blubber. Students are unable to detect many forms of carbon with their own senses or easily see the impact of these forms on the environment (Fig. 6).

Instructors carefully assessed students' baseline carbon knowledge and then proceeded to advance it. Interactive activities such as the carbon cycle game included student role playing carbon in different reservoirs (sinks): fossil fuels, atmosphere, or the ocean. A field trip to the Barrow Utilities and Electric Company provided a first-hand look at the carbonbased fuels that are burned to produce energy and transport water for the Barrow community.

Capitalizing on the wealth of Barrow's local and visiting scientific knowledge, the instructors invited scientists who spoke about climate change issues that reinforced the fundamental relationship of the carbon cycle to a changing climate. Students learned about changes occurring in weather patterns and their effect on the environment, the arctic wetlands and the millions of migratory birds that visit each summer, human and ecosystem interaction specifically on the tundra, how greenhouse gasses are impacting the environment, and the changing permafrost. During fieldtrips, students were exposed to a wide variety of instrumentation, covering remote sensing satellites,

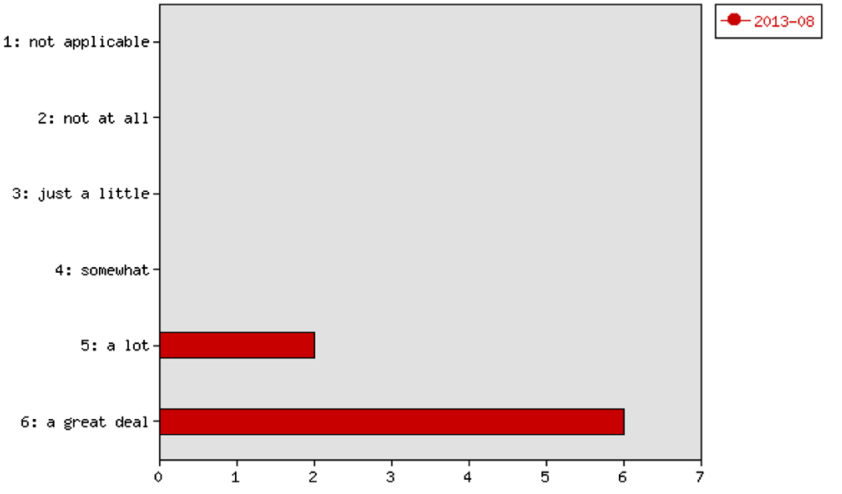

time lapse photography, and dynamic soil flux chambers to name only a few (Table 6).

Of equal importance was the opportunity to spend time with North Slope Elders who spoke of topics related to climate change: economics, storms, sea ice, polar bears, walrus, whales, caribou, ice cellars, invasive species, traditional knowledge and science, and adaptation and policy. For example, Elder Martha Stackhouse spoke about changing plant and animal migration patterns as the climate warms and invasive species are migrating north.

There are more sourdocks than ever, and the pussy willows are taller than they have ever been. Grass niches used to only be inches in diameters are now several feet in diameter. There are many new plants in Barrow; Fireweed now grows in Barrow, when it once did not. Cranberries and Labrador tea are coming further north. The berries (salmonberries and cranberries) are almost to Wainwright. (Martha Stackhouse, personal communication, July 2015.)

Students were thoroughly engaged during the Elders' visits. They listened intently and asked questions. Students learned from the Elders who shared their own personal experiences through stories while, at the same time, pass on traditional knowledge. As climate is warming fastest in the Arctic, 
Fig. 5 Student Assessment and Learning Gains (SALG) results for the question "I understand how topics covered can relate to my village." Pretest and post-test means were significantly different, $p \leq .009$
I understand how topics covered can relate to my village.

a

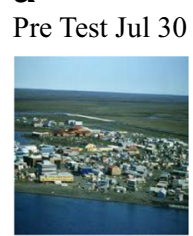

Mean 4.5

Std. 0.93

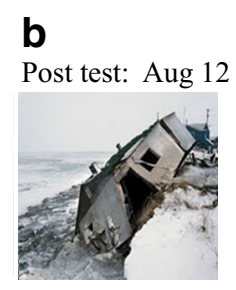

Mean 5.6

Std. 0.74 the students often have stories to tell from their own observations.

High school students, especially those from rural areas, rarely have the opportunity to interact with the scientific community. The course design planned on students obtaining information that would lead them to attend a scientific meeting. Three students (two from Wainwright, AK, and one from

Table 5 Student presentation titles

\section{Carbon dioxide}

Climate change affecting caribou

Climate change affecting geese

Climate change on the sea ice

Climate change: melting permafrost is affecting our ice cellars

Global warming in Alaska: sea ice

Global warming solutions

How climate change affects whales

Permafrost and greenhouse gases

Temperature effects

The difference between weather and climate change

The effects of climate change on land and infrastructure

Kate Cooper, Institute for Computing in Humanities, Arts and Social Science, assisted students with their public presentation preparations
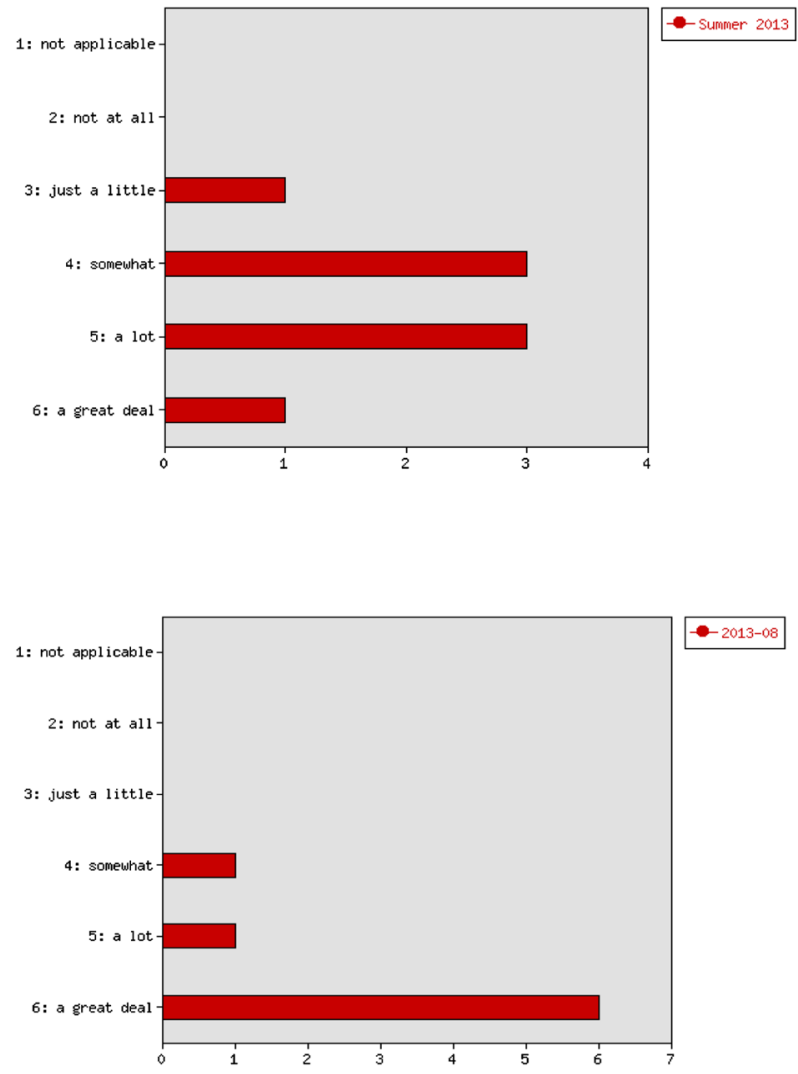

Shishmaref, AK) attended the Society for the Advancement of Chicanos/Hispanics and Native Americans in Science (SACNAS) National Conference, where they attended symposiums, leadership development seminars, poster (Fig. 7), and keynote sessions. Two Barrow students and one student from Point Lay were selected to attend the 18th Inuit Studies

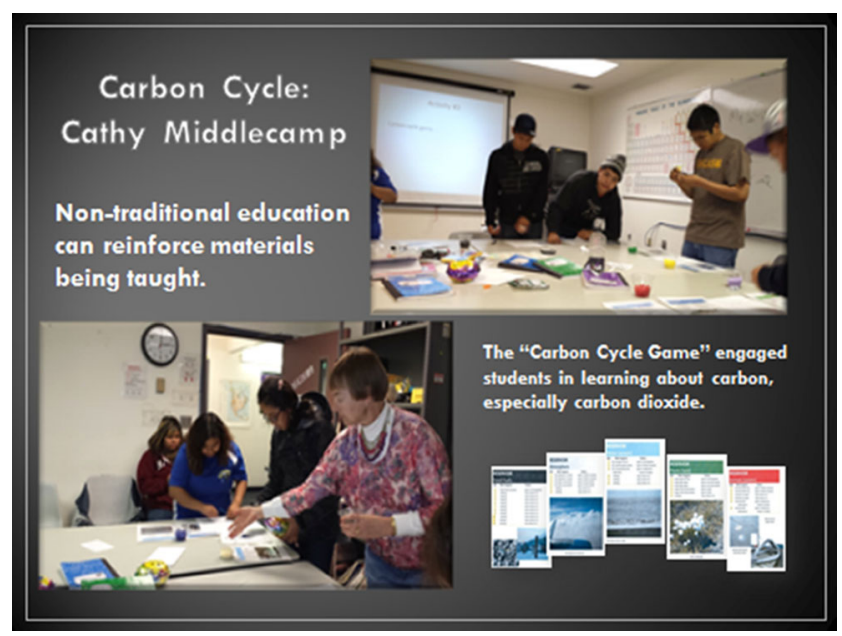

Fig. 6 Students learned about carbon and then played the Carbon Cycle Game reinforcing carbon's movement from air to land to water to plants and animals. Photograph by Linda Nicholas-Figueroa 
Table 6 North Slope fieldtrip presentations

\begin{tabular}{|c|c|c|}
\hline Scientist & Affiliation & Presentation details \\
\hline Dr. Bob Rabin & $\begin{array}{c}\text { NOAA, National Severe } \\
\text { Storms Laboratory }\end{array}$ & $\begin{array}{l}\text { Computer-based activities gave students an opportunity to } \\
\text { learn about remote observation, such as satellites, and } \\
\text { how they are used in climate research and weather } \\
\text { forecasting. Dr. Rabin explained satellite observations of } \\
\text { clouds, sea, ice, and land. Students used geostationary } \\
\text { satellite and NASA's high-resolution imagery for real- } \\
\text { time weather observations. Students watched annual ice } \\
\text { movement from scatterometers (space radar), analyzed } \\
\text { snow and ice cover change, interpreted weather forecast } \\
\text { models, and made their own weather forecasts. The film, } \\
\text { Inuit Observations on Climate Change, was shown. }\end{array}$ \\
\hline Dr. Christian Andersen & $\begin{array}{l}\text { University of Texas at El } \\
\text { Paso }\end{array}$ & $\begin{array}{l}\text { Dr. Andersen uses a combination of aquatic ecology and } \\
\text { remote sensing to understand long-term changes (biolog- } \\
\text { ical, hydrological, chemical) in the arctic wetlands. The } \\
\text { use of a kite rig and time-lapse photography for monitor- } \\
\text { ing was demonstrated. }\end{array}$ \\
\hline Dr. Robert Hollister & $\begin{array}{l}\text { Grand Valley State } \\
\text { University }\end{array}$ & $\begin{array}{l}\text { Interested in the interactions between humans and natural } \\
\text { ecosystems with an emphasis in vegetation change, Dr. } \\
\text { Hollister discussed the response of changing tundra to } \\
\text { global warming. Dr. Hollister discussed his findings on } \\
\text { how climate change is affecting tundra ecosystem land } \\
\text { use. }\end{array}$ \\
\hline $\begin{array}{l}\text { Drs. Eric Wilkman and } \\
\text { Katherine McEwing }\end{array}$ & $\begin{array}{l}\text { University of California } \\
\text { San Diego } \\
\text { University of Sheffield, } \\
\text { UK }\end{array}$ & $\begin{array}{l}\text { Drs. Wilkman and McEwing reinforced the importance of } \\
\text { understanding the carbon cycle. They provided a context } \\
\text { for the roles played by greenhouse gasses, permafrost, and } \\
\text { microbes and plants in the large-scale process and ex- } \\
\text { plained how changes in the Arctic affected the global } \\
\text { carbon cycle and impacted climate change. They included } \\
\text { explanations of methodology and instrumentation that } \\
\text { measure trace gas fluxes. Wilkman and McEwing invited } \\
\text { the students to the Barrow Environmental Observatory } \\
\text { and showed them the instrumentation (eddy covariance } \\
\text { towers, dynamic soil flux chambers) in action. }\end{array}$ \\
\hline
\end{tabular}

Conference in Washington, DC, where they delivered their community presentations on climate change and participated on a youth discussion panel.

Elise Patkotak, reporting for the Arctic Sounder, wrote

Student participant Kenneth Ivanoff told NicholasFigueroa, who accompanied the students to Washington, that he was excited about meeting so many people from so many different places in the world. He told her he learned a lot from the sessions he attended

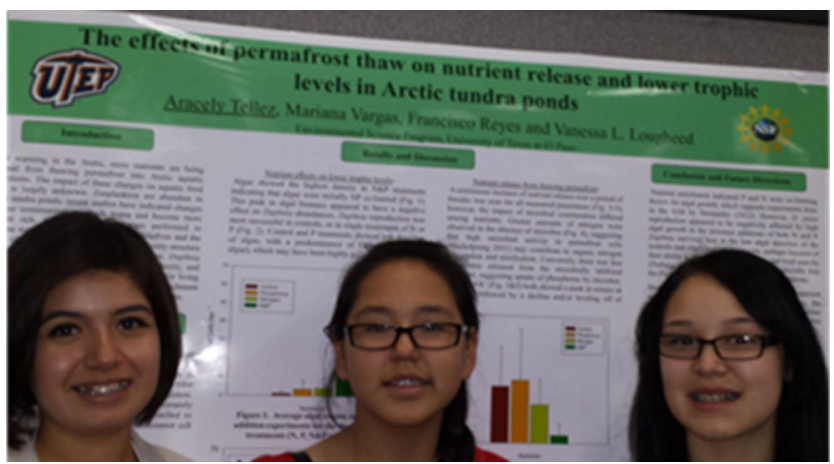

Fig. 7 Students attending SACNAS poster session. Photograph by Linda Nicholas-Figueroa and, in particular, enjoyed the plenary speech by Mark Serreze, Director of the National Snow and Ice Date Center. According to Ivanoff, Serreze "talked about things I learned in summer camp about the effects of global warming on sea ice and permafrost in the Arctic." Mead Treadwell, Alaska's Lt. Gov., also spoke and discussed "the State's work addressing cultural challenges, resource development, and environmental change." As liaison for Alaska to the Arctic Council, he addressed the issues of international geopolitics as it related to the work of the Arctic Council (Patkotak 2013).

\section{Future efforts}

Future effort will be devoted to the development of similar modules focused on TEK and STEM topics associated with community workforce development goals. Ilisagivik College offers STEM science camps for youth on the North Slope to introduce them to research being conducted in their immediate environment. Science curricula in the form of short courses such as a biotechnological skills workshop and citizen science projects with the North Slope Borough School District are being 
developed. Next steps include partnership with UMIAQ Science, a subsidiary of the Ukpeagivik Iñupiat Corporation, to create internships for college and high school students to work with local and visiting scientists in Barrow. Climate change is a complex system involving both ecosystem services and human social and political systems. Both the social issues and the science can be used to engage students (Duffy et al. 2011a).

Our goal is to engage students so that they can see STEM's abstract (invisible) concepts in their lives and communities. It is practical to combine the traditional, holistic world view of the community with the reductionist scientific approach. The community's perspective is that "Western science" has much to learn from traditional ecological knowledge (TEK) and its associated values of living on the land. In order to maintain a dynamic culture, it is essential that TEK be a strong component of their children's education for their long-term well-being.

\section{Conclusion}

This summer STEM program is an informal way of engaging students in science concepts while seeing the relevance to realworld issues. Student assessment showed an increase in knowledge to how real-world issues can directly relate to community concerns, such as the local challenges of adapting to a changing climate. By connecting the science to the region, cultural traditions and values are inserted into the learning experience. This interdisciplinary approach makes the science, as well as the social, economic, and cultural relationships, visible. Teaching science in a holistic, informal context with both Western and TEK provides a balanced perspective as we educate tomorrow's leaders and decision makers.

Acknowledgments We would like to acknowledge our partnerships with the following organizations: American Indian Higher Education Consortium, University of Illinois Urbana Champaign, Smithsonian Institution's National Museum of the American Indian, the Arctic Division of the American Association for the Advancement of Science, and the Arctic Slope Community Foundation, grants ASCF005 and ASCF026. We are also grateful for the very helpful comments of the three anonymous reviewers.

Open Access This article is distributed under the terms of the Creative Commons Attribution 4.0 International License (http://creativecommons.org/licenses/by/4.0/), which permits use, duplication, adaptation, distribution and reproduction in any medium or format, as long as you give appropriate credit to the original author(s) and the source, provide a link to the Creative Commons license and indicate if changes were made.

\section{References}

Barnhardt R (2005) Culture, community, and place in Alaska Native education. Democracy and education., http://ankn. uaf/Curriculum/Articles/RayBarnhardt/CultureCommPlaceANE. html. Accessed October 20, 2016
BUECI (2015) Barrow Utilities and Electric Co., Inc., www.bueci.org. Accessed October 26, 2015

Department of Energy (2015) Atmospheric radiation measurements: climate research facility., https://www.arm.gov. Accessed October 26, 2015

Duffy L, Godduhn A, Fabbri C, van Muelken M, Nicholas-Figueroa L, Middlecamp C (2011a) Engaging students in science courses: lessons of change from the Arctic. Interchange A Quarterly Review of Education 42(2): 105-139

Duffy L, Godduhn A, Dunlap K, van Muelken M, Middlecamp C (2011b) Sustainability and chemistry: key concepts in an Arctic focused interdisciplinary course. In: Middlecamp C, Jorgenson A (eds) Sustainability in the chemistry curriculum. American Chemical Society Symposium, Washington, 1087:97-112

EPA (2015) Environmental Protection Agency: Climate Impacts in Alaska., http://www3.epa.gov/climatechange.html. Accessed October 26, 2015

Lowan G (2012) Expanding the conversation: further explorations into Indigenous environmental science education theory, research, and practice. Cultural Studies of Science Education 7:71-81. doi:10.1007/s11422-012-9379-1

Mazzocchi F (2006) Western science and traditional knowledge: despite their variations, different forms of knowledge can learn from each other. EMBO Report. Science and Society Viewpoint 7(5):463-466. doi:10.1038/sj.embor.7400693, PMICD: PMC1479546

Medin D, Bang M (2014) Who's asking? Native science, Western science and science education. MIT Press, Cambridge

Nakashima D, Roué M (2002) Indigenous knowledge, peoples and sustainable practice. In: Timmerman P (ed) Encyclopedia of global environmental change. 5: social and economic dimensions of global environmental change. Wiley, Chichester, pp 314-324

Nicholas-Figueroa L, Barnhardt R, Duffy L, Dunlap K, Middlecamp C (2015) Delivering post-secondary STEM education on the North Slope, Alaska: resilience and adaptation. International Research in Education 3(2):80-92

NOAA. ESRL. GMD (2015) NOAA Earth System Research Laboratory, Global Monitor Division., www.esrl.noaa.gov/gmd/. Accessed October 26, 2015

NOAA. NWS (2015) NOAA National Weather Services. Alaska Region Headquarters., http://www.arh.noaa.gov. Accessed October 26, 2015

NSB (2016) Official Website of the North Slope Borough, http://www. north-slope.org/information/visitors-information. Accessed May 10, 2016

Patkotak E (2013) North Slope students travel to D.C. for Inuit Studies Conference, The Arctic Sounder., Retrieved from www. thearcticsounder.com

Perkins J, Middlecamp C, Blockstein D, Cole J, Knapp R, Saul K, Vincent S (2014) Energy education and the dilemma of mitigating climate change. Journal Environmental Studies and Sciences 4:354-359

SALG (2013) Student Assessment of Learning Gains, http://www. salgsite.org/instructor/signin; http://www.salgsite.org. Accessed December 22, 2015

Sea Ice Group UAF (2015) Sea Ice Group at the Geophysical Institute. University of Alaska Fairbanks, http://seaice.alaska.edu/gi/. Accessed October 26, 2015

Seymour E, Wiese D, Hunter A, Daffinrud SM (2000) Creating a better mousetrap: on-line student assessment of their learning gains., National Meeting of the American Chemical Society, http://www. salgsite.org. Accessed December 23, 2015

Shepro C (2010) The North Slope Borough Economic Profiles and Census Reports., http://www.north-slope. org/departments/mayorsoffice/census_data_2010.php. Accessed January 4, 2014

Stephens (2000) Handbook for culturally-responsive science curriculum. Alaska Science Consortium and the Alaska Rural Systemic Initiative 